\title{
Peningkatan Adaptibilitas Gembili (Dioscorea esculenta L.) pada Lahan Pesisir dengan Penambahan Pupuk Amonium Sulfat (ZA) dan Mulsa Organik
}

\author{
Increasing Lesser Yam's (Dioscorea esculenta L.) adaptability on Coastal \\ Land with the Application of Ammonium Sulphate (ZA) Fertilizer and \\ Organic Mulch
}

\author{
Catur Herison*, Edhi Turmudi, Merakati Handayaningsih, Kurnia Herlina Dewi \\ Jurusan Budidaya Pertanian, Fakultas Pertanian, Universitas Bengkulu \\ *:herisoncatur@yahoo.com
}

\begin{abstract}
Increasing plant capability to adapt on coastal land is very important aspect in the development alternative carbohydrate source food. The objective of this research is to determine the effect of $Z A$ fertilizer and organic mulch on lesser yam's adaptability based on its growth and yield. The experiment was conducted with a randomized completely block design arranged in a split plot with 3 replications. As the Main Plot were organic mulch levels, and as the Sub Plot were ZA fertilizer doses. The results showed that there was no interaction effect between ZA fertilizer and organic mulch on either growth or yield of lesser yam. Application of ZA fertilizer up to $200 \mathrm{~kg} \mathrm{ha}^{-1}$ improve lesser yam's adaptability based on their vegetative growth. Organic mulch of rice paddy straw up to the rate of 20 ton ha ${ }^{-1}$ did not increase growth and yield of lesser yam in coastal sandy land.
\end{abstract}

Key words: ZA, organic mulch, lesser yam, adaptability

\begin{abstract}
ABSTRAK
Peningkatan kemampuan tanaman untuk beradaptasi terhadap kondisi lahan kawasan pesisir penting dalam pengembangan tanaman alternatif sumber karbohidrat. Tujuan penelitian ini adalah untuk mengetahui pengaruh pemberian dosis pupuk ZA dan mulsa organik terhadap adaptibilitas tanaman gembili yang diukur berdasarkan pertumbuhan dan hasil. Percobaan dilakukan dengan rancangan kelompok lengkap teracak yang disusun dalam split plot dengan 3 ulangan, dengan perlakukan mulsa sebagai petak utama dan ZA sebagai anak petak. Hasil percobaan menunjukkan bahwa tidak terdapat pengaruh interaksi antara dosis pupuk ZA dan aplikasi mulsa jerami terhadap pertumbuhan tanaman gembili. Pemberian pupuk ZA hingga $200 \mathrm{~kg} \mathrm{ha}^{-1}$ meningkatkan adaptibilitas gembili pada lahan pesisir yang ditunjukkan melalui peningkatan pertumbuhan vegetatif tanaman. Mulsa jerami hingga dosis 20 ton ha ${ }^{-1}$ tidak memberikan efek yang signifikan terhadap adaptibilitas tanaman pada lahan pesisir.
\end{abstract}

Kata kunci: ZA, mulsa organik, gembili, adaptabilitas. 


\section{PENDAHULUAN}

Gembili merupakan salah satu spesies dalam famili uwi-uwian (dioscorea) yang cukup potensial sebagai pangan alternatif sumber karbohidrat di lahan marginal (Herison et al., 2010). Tanaman tersebut memerlukan tanah berstruktur gembur untuk dapat menghasilkan umbi yang baik (French, 2006). Kondisi fisik tanah pasir kawasan pesisir memenuhi persyaratan bagi perkembangan umbi tanaman tersebut.

Kawasan pesisir adalah kawasan yang mengalami pengaruh lingkungan laut yang sangat kuat. Masalah utama lahan salin adalah kandungan garam yang tinggi terutama $\mathrm{Na}^{+}$dan $\mathrm{Cl}^{-}$(Widjaya, 1986). Salinitas sering merupakan faktor pembatas bagi pertumbuhan dan hasil tanaman. Terganggunya pertumbuhan tanaman karena kadar garam yang tinggi, menurut disebabkan oleh dua hal; pertama, menurunnya potensial air pada media tumbuh menyebabkan penyerapan air oleh akar tanaman sangat terbatas; kedua, akumulasi ion-ion tertentu menyebabkan keracunan pada tanaman. Tetapi yang lebih umum te jadi adalah kesukaran dalam penyerapan air. Berkurangnya serapan air mempengaruhi proses fotosintesis, metabolisme karbohidrat, dan pergerakan fotosintat dalam tanaman (Salisbury dan Ross, 1992). Perubahan-perubahan tersebut dapat berakibat bagi rendahnya hasil. Selain itu, tanah pesisir umumnya mengandung C-Organik sebesar $<1 \%$, yang termasuk kategori sangat rendah dan tidak baik bagi pertumbuhan tanaman (Hasibuan, 2008).

Peningkatan pasokan unsur nitrogen sebagai unsur penyusun protein dan molekul berbobot rendah dapat meningkatkan ketahanan tanaman terhadap kondisi tercekam (Marshcner, 1986). Selain itu, peningkatan pupuk nitrogen secara umum dapat meningkatkan pertumbuhan tanaman (Salisbury dan Ross, 1992).

Persoalan lainnya adalah bahwa lahan pesisir didominasi oleh tanah pasir dengan kandungan bahan organik rendah sehingga sangat mudah kering jika diolah dan terpapar matahari. Mulsa organik dapat berperan ganda dalam budidaya tanaman yaitu sebagai mulsa dan jika telah lapuk dapat memasok bahan organik.

Tujuan penelitian ini adalah untuk mengetahui pengaruh pemberian pupuk ZA dan mulsa organik terhadap adaptibilitas tanaman gembili di lahan pesisir.

\section{METODE PENELITIAN}

Percobaan dilakukan di kawasan pesisir, yaitu Desa Lempuing, Kecamatan Teluk Segara, Kota Bengkulu. Percobaan dilakukan pada bulan Mei 2012 sampai April 2013. Bahan yang diperlukan dalam kegiatan ini adalah benih (umbi) gembili, pupuk ZA, TSP dan $\mathrm{KCl}$, serta pestisida untuk pengendalian hama dan patogen secara preventif. Alat yang digunakan dalam tahapan ini meliputi alat pertanian dan alat ukur seperti meteran panjang, timbangan dan jangka sorong, leaf area meter, dan chlorofil meter. 
Rancangan percobaan yang digunakan adalah rancangan acak kelompok lengkap Split Plot dengan 3 ulangan. Sebagai petak utama adalah taraf bobot mulsa organik batang padi, yaitu 0,10 , atau 20 ton $\mathrm{ha}^{-1}$. Sedangkan sebagai Anak Petak adalah taraf dosis ZA yang meliputi 0,100 atau $200 \mathrm{~kg} \mathrm{ha}^{-1}$.

Oleh karena lahan percobaan merupakan lahan pasir, maka penyiapan lahan hanya dilakukan dengan pembersihan gulma tanpa pencangkulan. Gulma dan sisa tanaman sebelumnya dibersihkan dengan arit. Selanjutnya dibuat 3 petakan besar sebagai ulangan (blok) dengan jarak $2 \mathrm{~m}$. Pada masing-masing ulangan dibuat petak-petak utama dengan cara membuat parit dangkal selebar $30 \mathrm{~cm}$ dengan kedalam $30 \mathrm{~cm}$. Penentuan letak petak utama dilakukan secara acak. Pada setiap petak utama selanjutnya dibuat anak-anak petak dengan ukuran $3 \mathrm{~m}$ x $5 \mathrm{~m}$ dengan jarak antar petak $30 \mathrm{~cm}$.

Penanaman dilakukan dengan jarak tanam $75 \mathrm{~cm}$ x $50 \mathrm{~cm}$ Penanaman dilakukan dengan cara mebuat lubang-lubang tanam dengan cangkul sedalam $10 \mathrm{~cm}$, dan umbi bibit uwi dimasukkan kedalam lubang tersebut selanjutnya ditimbun dan dipadatkan.

Pemberian pupuk dasar dilakukan dengan cara tugal, $10 \mathrm{~cm}$ dari umbi ditanam, dengan dosis $150 \mathrm{~kg} \mathrm{SP36/ha} \mathrm{dan} 100$ $\mathrm{kg} \mathrm{KCl/ha} \mathrm{pada} \mathrm{saat} \mathrm{tanam.} \mathrm{Pupuk} \mathrm{ZA} \mathrm{di-}$ berikan sesuai dengan perlakuan diberikan dua kali, yaitu setengah dosis pada saat ta- nam dan sisanya pada 30 HST (hari setelah tanam). Mulsa dipasang setelah penanaman dan pemupukan selesai, sesuai dengan perlakuan, dengan cara menata batang padi secara merata di atas lahan yang telah ditanami bibit. Bobot mulsa akan menentukan ketebalan mulsa.

Pemeliharaan tanaman meliputi pengendalian organisme pengganggu tanaman (OPT) dan pemberian ajir. Pengendalian OPT dilakukan secara preventif dengan penyemprotan insektisida dan fungisida secara berkala 1 bulan sekali. Pemberian ajir dimulai ketika tanaman berumur 30 HST. Ajir yang digunakan adalah ajir bambu dengan panjang $3 \mathrm{~m}$.

Pengamatan dilakukan terhadap variabel pertumbuhan yang meliputi panjang tanaman, jumlah daun, luas daun, tingkat kehijauan daun dan bobot brangkasan segar dan kering. Variabel hasil yang diamati meliputi bobot umbi, jumlah umbi, diameter umbi dan panjang umbi. Analisis data dilakukan menggunakan analisis varian (ANOVA) dan uji lanjut BNT.

\section{HASIL DAN PEMBAHASAN}

Hasil analisis varians menunjukkan bahwa tidak terdapat interaksi antara perlakukan pupuk ZA dengan mulsa organik jerami padi terhdap pertumbuhan tanaman uwi. Pola respon pertumbuhan tanaman, yang diukur berdasarkan tingkat kehijauan daun, diameter, jumlah rata-rata ruas per $\mathrm{m}$ dan luas daun, terhadap perlakukan pupuk ZA adalah sama pada setiap tingkat pem- 
berian mulsa. Perlakuan mulsa ditujukan untuk memperlambat kehilangan lengas tanah, sementara itu pupuk ZA dimaksudkan untuk menambah unsur hara, terutama nitrogen, yang dibutuhkan oleh tanaman. Peningkatan dosis pupuk ZA meningkatkan pertumbuhan dalam tingkat yang tidak berbeda baik pada perlakukan tanpa mulsa maupun pada pemberian mulsa 10 ton atau 20 ton $\mathrm{ha}^{-1}$.

Tidak terlihatnya efek interaksi antara penambahan pupuk ZA dengan pemberian mulsa tersebut diduga berkaitan dengan lambatnya pertumbuhan tanaman yang lebih dari 3 bulan. Dalam masa 3 bulan tersebut, pada kondisi panas dan lembab lingkungan pesisir sebagai dampak dari laut, mulsa yang diberikan sudah mengalami pelapukan dan tidak lagi berfungsi menutupi areal pertanaman. Oleh karenanya, ketika tanaman sudah tumbuh, mulsa tidak lagi berfungsi secara baik, dan antara ketiga taraf mulsa yang digunakan relatif tidak terdapat perbedaan visual di lapangan.

Hasil analisis varian menunjukkan bahwa peningkatan dosis pupuk ZA berpengaruh signifikan terhadap komponen pertumbuhan gembili. Tingkat kehijauan daun meningkat dengan meningkatnya dosis pupuk ZA yang ditambahkan hingga $200 \mathrm{~kg} \mathrm{ha}^{-1}$. Pada tanaman uwi, penambahan $100 \mathrm{~kg} \mathrm{ZA/ha} \mathrm{meningkatkan} \mathrm{kehijauan}$ daun yang signifikan. Peningkatan dosis hingga $200 \mathrm{~kg} \mathrm{ha}^{-1}$, tingkat kehijauan daun lebih meningkat lagi (Tabel 1). Sementara itu, penambahan pupuk hingga $100 \mathrm{~kg} \mathrm{ha}^{-1}$ menyebabkan peningkatan kehijauan daun sekalipun tidak signifikan secara statistik. Peningkatan yang nyata baru terlihat pada dosis $200 \mathrm{~kg} \mathrm{ha}^{-1} \mathrm{ZA}$ (Tabel 1). Peningkatan pupuk ZA berarti meningkatkan suplai unsur nitrogen bagi tanaman, dan salah satu efek yang umum terlihat dengan penambahan unsur nitrogen adalah tanaman menjadi lebih hijau (Salisbury dan Ross, 1992). Tingkat kehijauan daun yang diukur berdasarkan nilai bacaan alat SPAD mencerminkan tingkat kandungan klorofil pada daun (Azis dan Stewart, 2001). Kandungan klorofil yang tinggi sangat penting dalam proses fotosintesis tanaman sehingga proses fotosintesis menjadi lebih tinggi dan akumulasi fotosintat ke dalam sink menjadi lebih baik.

Diameter batang meningkat signifikan pada aplikasi $200 \mathrm{~kg} \mathrm{ha}^{-1} \mathrm{ZA}$. Sedangkan luas daun meningkat pada dosis $100 \mathrm{~kg}$ $\mathrm{ha}^{-1}$ yang tidak berbeda dengan dosis 200

Tabel 1. Pengaruh dosis pupuk ZA terhadap komponen pertumbuhan gembili

\begin{tabular}{|c|c|c|c|c|c|}
\hline $\begin{array}{c}\text { Dosis } \\
\text { pupuk ZA }\end{array}$ & $\begin{array}{c}\text { Kehijauan } \\
\text { daun }\end{array}$ & $\begin{array}{c}\text { Diameter } \\
\text { batang }(\mathrm{mm})\end{array}$ & Jumlah ruas* & $\begin{array}{l}\text { Jumlah } \\
\text { cabang }\end{array}$ & $\begin{array}{l}\text { Luas daun } \\
\left(\mathrm{cm}^{2}\right)^{* *}\end{array}$ \\
\hline 0 & $30.98 \mathrm{~b}$ & $1.91 \mathrm{a}$ & $17 \mathrm{a}$ & $6 a$ & $51.85 \mathrm{~b}$ \\
\hline 100 & $33.06 \mathrm{ab}$ & $1.96 \mathrm{a}$ & $17 \mathrm{a}$ & $7 \mathrm{a}$ & $65.83 \mathrm{a}$ \\
\hline 200 & $34.49 \mathrm{a}$ & $2.32 \mathrm{~b}$ & $17 \mathrm{a}$ & $7 \mathrm{a}$ & $67.99 \mathrm{a}$ \\
\hline
\end{tabular}


$\mathrm{kg} \mathrm{ha}^{-1} \mathrm{ZA}$. Sementara itu, peningkatan pupuk nitrogen tersebut tidak meningkatkan jumlah ruas maupun jumlah cabang per 1.5 m (Tabel 1).

Secara keseluruhan, peningkatan pupun nitrogen dalam bentuk ZA hingga 200 $\mathrm{kg} \mathrm{ha}^{-1}$ meningkatkan komponen pertumbuhan vegetatif yang diamati. Hasil serupa juga diperoleh Ajayi et al. (2006). Nitrogen di dalam tanaman terdapat dalam bentuk senyawa asam amino, peptida, amida, ureida dan amina. Senyawa yang memiliki bobot melekul rendah tersebut merupakan penyusun protein (enzim dan protein struktural), asam nukleat dan senyawa lain (koenzim, metabolit sekunder, dan penyusun membran). Senyawa nitrogen organik tersebut di dalam tanaman berperan penting dalam berbagai aktivitas tumbuh kembang tanaman, antara lain menentukan osmoregulasi sel, transport berbagai unsur lain, pembelahan sel, menjaga keseimbangan kation-anion serta $\mathrm{pH}$ dalam sel dan berbagai reaksi enzimatis (Marschner, 1986). Oleh karena itu peningkatan ketersediaan nitrogen dalam tanah mendorong terjadi peningkatan senyawa nitrogen organik dalam tanaman yang pada akhirnya dapat meningkatkan pertumbuhan vegetatif tanaman.

Selain itu, pada kondisi terjadinya cekaman salinitas, terjadi peningkatan senyawa prolin dan betain (terutama glycin betain) yang merupakan senyawa nitrogen organik. Senyawa tersebut berperan melindungi inaktivasi enzim akibat konsentrasi $\mathrm{NaCl}$ yang tinggi dan melindungi destabilisasi membran akibat suhu tinggi. Oleh karenanya, senyawa nitrogen organik berperan sangat penting dalam adaptasi tanaman terhadap lingkungan salinitas (Marschner, 1986). Dengan demikian penambahan ketersediaan unsur nitrogen melalui pemupukan memungkinkan tanaman tumbuh lebih baik dalam kondisi salinitas tinggi.

$\mathrm{ZA}$ adalah pupuk sumber $\mathrm{N}$ dengan kandungan amonium dan sulfat. ion sulfat diharapkan dapat menggantikan ion $\mathrm{Cl}$ dalam larutan tanah sehingga efek toxisitas $\mathrm{Cl}$ dapat dinetralisir. Berdasarkan pengamatan visual gejala keracunan $\mathrm{Cl}$ pada tanaman dengan perlakuan ZA maupun kontrol tidak tampak. Hal tersebut menunjukkan bahwa tanaman gembili, bahkan mungkin jenis dioscorea lainnya, cukup toleran terhadap kondisi salinitas.

Hasil analisis ragam menunjukkan bahwa mulsa tidak berpengaruh nyata terhadap komponen pertumbuhan vegetatif gembili. Aplikasi mulsa jerami padi hingga 20 ton ha $^{-1}$ (kira-kira dengan ketebalan 5 $\mathrm{cm})$ tidak menyebabkan terjdinya peningkatan pertumbuhan vegetatif tanaman. Pengukuran terhadap tingkat kehijauan daun, diameter batang, jumla ruas dan luas daun pada tanaman gembili pada perlakukan mulsa tidak berbeda dengan tanpa mulsa (Tabel 2).

Mulsa secara umum adalah bahan yang digunakan untuk menutup lahan yang ditujukan antara lain untuk menghambat pertumbuhan gulma dan mengurangi laju 
Tabel 2. Pengaruh dosis pemberian mulsa jerami terhadap komponen pertumbuhan gembili

\begin{tabular}{|c|c|c|c|c|c|}
\hline $\begin{array}{l}\text { Mulsa (ton } \\
\text { ha-1) }\end{array}$ & $\begin{array}{l}\text { Kehijauan } \\
\text { daun }\end{array}$ & $\begin{array}{c}\text { Diameter } \\
\text { batang }(\mathrm{mm})\end{array}$ & $\begin{array}{l}\text { Jumlah }^{*} \\
\text { ruas }\end{array}$ & $\begin{array}{l}\text { Jumlah } \\
\text { cabang }\end{array}$ & $\begin{array}{l}\text { Luas daun }^{* *} \\
\quad\left(\mathrm{~cm}^{2}\right)\end{array}$ \\
\hline 0 & $33.70 \mathrm{a}$ & $2.05 \mathrm{a}$ & $18 \mathrm{a}$ & $7 \mathrm{a}$ & $61.05 \mathrm{a}$ \\
\hline 10 & $32.39 \mathrm{a}$ & $2.21 \mathrm{a}$ & $17 \mathrm{a}$ & $7 \mathrm{a}$ & $60.68 \mathrm{a}$ \\
\hline 20 & $32.44 \mathrm{a}$ & $1.93 \mathrm{a}$ & $16 \mathrm{a}$ & $6 \mathrm{a}$ & $63.94 \mathrm{a}$ \\
\hline
\end{tabular}

kehilangan lengas tanah. Agar dapat berfungsi secara efektif, mulsa harus berada dalam kondisi menutup tanah secara baik pada saat diperlukan oleh tanaman. Di dalam penelitian ini, aplikasi mulsa dilakukan pada awal penanaman dengan asumsi bahwa ketika tanaman tumbuh, 2-3 minggu setelah tanam, mulsa berfungsi membantu menjaga kelengasan tanah yang dibutuhkan oleh tanaman muda pada kondisi kemarau. Oleh karena terjadi keterlambatan perkecambahan umbi bibit yang ditanam hingga 3 bulan, maka ketika tanaman baru mulai tumbuh, mulsa jerami sudah lapuk sehingga efek yang diharapkan menjadi tidak nyata. Keterlambatan perkecambahan umbi disebabkan oleh umbi bibit yang ditanam masih dalam periode dormansi (Wickham et al., 1981: Suttle, 1996) Kondisi kelengasan tanah yang lebih baik pada perlakukan mulsa belum dapat dimanfaatkan oleh umbi bibit uwi maupun gembili yang ketika itu masih dorman secara fisiologis.

\section{KESIMPULAN}

Tidak terdapat pengaruh interaksi antara dosis pupuk ZA dan aplikasi mulsa jeramit terhadap pertumbuhan tanaman gembili. Pemberian pupuk ZA hingga $200 \mathrm{~kg} \mathrm{ha}^{-1}$ meningkatkan adaptibilitas gembili pada lahan pesisir yang ditunjukkan melalui peningkatan pertumbuhan vegetatif tanaman. Mulsa jerami hingga dosis 20 ton ha ${ }^{-1}$ tidak memberikan efek yang signifikan terhadap adaptibilitas tanaman pada lahan pesisir.

\section{SANWACANA}

Terima kasih penulis sampaikan kepada Bp. Budiyanto yang telah menyewakan lahan pertaniannya untuk penelitian ini. Terima kasih juga disampaikan kepada Samuel Aritonang untuk pemeliharaan tanaman di lapangan.

\section{DAFTAR PUSTAKA}

Ajayi, S.S., E.A. Akinrinde, and R. Asiedu. 2006. Fertilizer treatment effect on yam (Dioscorea spesies) tuber yield in two soil types of Nigeria. J.Agron. 5(3):492-496

Azis, F. and K. A. Stewart. 2001. Relationships between extractable chlorophyll and SPAD values in muskmelon leaves. Journal of Plant Nutrition 24(6): 961-966.

French, B.R. 2006. Food plants of Papua New Guinea. A compendium. Revised edition. Privately published 
as an electronic book in pdf format. 38 West St., Burnie. Tasmania 7320 . Australia. Email: bfrench@vision. net.au

Hasibuan, B. E. 2008. Pengelolaan Tanah dan Air Lahan Marginal. USU Press, Medan.

Herison, C., E. Turmudi dan M. Handayaningsih. 2010. Studi Kekerabatan Genetik Asesi Uwi (Dioscorea) Yang Dikoleksi Dari Beberapa Daerah Di Indonesia. Akta Agrosia. 13(1):55-61

Marschner, H. 1986. Mineral Nutrition of Higher Plants. Academic Press. London.

Salisbury, F.B. and C.W. Ross. 1992. Plant
Physiology. $4^{\text {th }}$ Edition. Wadsworth Publ.Co. Belmont California. 682p. Suttle, J.C. 1996. Dormancy in tuberous organs: problems and perspec-tives. In: Lang GA, ed. Plant dormancy: physiology, biochemistry and molecular biology. Wallingford, UK: CAB International, 133-146.

Wickham, L.D., L.A. Wilson, and H.C. Passam. 1981. Tuber germination and early growth in four edible Dioscorea species. Annals of Botany 47: 87-95.

Widjaja A, I. P. G. 1986. Pengelolaan lahan rawa pasang surut dan lebak. Pusat Penelitian Tanah. Bogor. 